\title{
Can the Construction of Social Credit System Alleviate the Influence of Financing Constraints on the Growth of Enterprises?
}

\author{
Kangyi Lin \\ School of Economy, Jinan University, Guangzhou, China \\ Email:xxh217@163.com
}

How to cite this paper: Lin, K.Y. (2019) Can the Construction of Social Credit System Alleviate the Influence of Financing Constraints on the Growth of Enterprises? Modern Economy, 10, 1253-1270. https://doi.org/10.4236/me.2019.104086

Received: March 27, 2019

Accepted: April 16, 2019

Published: April 19, 2019

Copyright (อ 2019 by author(s) and Scientific Research Publishing Inc. This work is licensed under the Creative Commons Attribution International License (CC BY 4.0).

http://creativecommons.org/licenses/by/4.0/

\section{(c) (i) Open Access}

\begin{abstract}
The construction of social credit system is an important prerequisite and objective need for the orderly and healthy development of market economy. Through the mechanism of credit information sharing and credit joint reward and punishment mechanism, it reduces information asymmetry and reveals the merits and demerits of social subject credit. It integrates the whole social forces to praise the good faith, punish the breach of trust, and creates a good credit environment. It is a common phenomenon that enterprises are faced with financing constraints which are not conducive to the growth and development of enterprises. This paper examines the influence of the construction of social credit system on the relationship between financing constraints and enterprise growth. It is found that the construction of social credit system can alleviate the adverse effects of financing constraints on the growth of enterprises, which is more obvious in non-state-owned enterprises.
\end{abstract}

\section{Keywords}

Construction of Social Credit System, Financing Constraints, Growth of Enterprises

\section{Introduction}

Enterprises are important participants in the market economy, whose development is closely related to the economic development of our country. However, the growth and development of enterprises have long been affected by financing constraints. Financing constraints can inhibit the outward foreign direct investment activities of enterprises (Zhang Aimei and others, 2019) [1], and then affect the relationship between foreign direct investment activities and enterprise 
performance. Financing constraints will also affect the export behavior of enterprises (Zhang Shikun, 2018) [2] and the research and development (R \& D) behavior of enterprises (Ju Xiaosheng and others, 2013; Wu Xiaofen and others, 2018) [3] [4].

Among them, the impact of financing constraints on the growth of enterprises has been the focus of academic attention. Financing is an important condition to determine the growth of enterprises, and small and medium-sized enterprises with large financing constraints are more likely to be unable to grow or even die (Marris, 1963; Eisenhardt and Schoonhoven, 1990) [5] [6] because of lack of funds. There are many ways of financing, including internal and external financing, while formal financing channels in external financing, especially bank credit allocation, have "credit discrimination" (Rao Pingui and Jiang Guohua, 2013; Zhang Xinmin and Zhang Tingting, 2016; Zhang Shikun, 2018) [2] [7] [8]. Banks and other formal financial institutions in system are more inclined to put credit resources into the state-owned economy, while private enterprises, especially small and medium-sized enterprises, are facing stronger external financing barriers (Zhang Jie, 2000) [9]. This can be attributed to the fact that under the asymmetric information, enterprises can use their information advantages to harm the financial institutions and make financial institutions bear too many risks. It is difficult for financial institutions to effectively identify the credit propensity of enterprises and insufficient credit quotas are allocated to private enterprises, which leads to the financing difficulties and credit crisis that affect the growth of enterprises (Zhao Chi, 2012) [10]. To break this dilemma, on the one hand, from the perspective of the external environment, we need to build a good institutional environment. The perfect system credit environment can reduce the risk of $\mathrm{R} \& \mathrm{D}$ and promote the innovation behavior under the restriction of enterprise financing ( $\mathrm{Wu}$ Xiaofen and others, 2018) [4]. The improvement of the degree of financial marketization can reduce the barriers and financing costs of the financial market and reduce the restraining effect on the export of enterprises. What's more, the credit environment can influence the bank loan decision (Qian Xianhang and Cao Chunfang, 2013; Qian Xianhang and Cao Ting, 2015) [11] [12], so a good credit environment can weaken the financing constraints of enterprises. On the other hand, proceeding from the decision behavior inside the enterprise, the operation capital management has a smooth effect on innovation when the enterprise innovation activities are facing financing constraints, and the more serious the constraints are, the more prominent this smooth effect will be (Ju Xiaosheng et al., 2013) [3]. For most enterprises restricted by bank credit, commercial credit is an important way to broaden their informal financing channels and break the financing dilemma (Zhang Xinmin and Zhang Tingting, 2016) [8].

Because the moral standard of market economy in our country has not been established, the supervision mechanism of social credit management has not been perfected, and the problem of lack of credit makes the investment activities 
of enterprises and banks tend to be cautious and shrink, and it hinders the capital market capital flow and financing. Moreover, the poor credit transmission mechanism cannot accurately quantify the credit ability of enterprises and increase the difficulty of enterprise financing (Chen Yan, 2016; Zhao Chi, 2012) [13] [10]. Therefore, the construction of social credit system can effectively solve the problem of lack of credit in the market economy. It reduces the asymmetry of information through the mechanism of credit information sharing which enables enterprises to share credit information. At the same time, it solves the problem of credit deficiency of the market subjects through the joint reward and punishment mechanism. Under the consideration of the construction of social credit system in China, this paper matches the commercial credit environment index of Chinese cities in 2010-2017 and the financial data of listed companies in China during 2010-2017 and it studies whether the construction of social credit system can effectively moderate the influence of financing constraints on the growth of enterprises.

In summary, the previous literature mainly studies the relationship between financing constraints and enterprises from the aspects of the causes of financing constraints, the impact of financing constraints on enterprises and the method of mitigating financing constraints on enterprises, while few literature studies the relationship between financing constraints and enterprises development from the perspective of breaking through financing constraints. Under information asymmetry, enterprises are faced with financing constraints not only by their own internal factors, but also by the imperfect establishment of external mechanisms and the poor transmission of enterprise credit information. It is inevitably limited if we only look for breakthroughs from the enterprise. This requires social governance mechanism such as social credit system to improve the external environment of enterprise production, operation and financing. Only when the social credit system is established can the burden of enterprise financing on enterprise growth be alleviated fundamentally. Combining the construction of social credit system to study financing constraints and enterprise growth, and to study the effectiveness of the construction of social credit system to solve the information asymmetry faced by enterprises and financing institutions is the innovation of this paper, which can provide theoretical supplement for the follow-up study of enterprise financing, and also provide practical reference value and useful suggestions for the construction of social credit system.

The article is organized as follows: The second part is the theoretical analysis and research hypothesis; the third part is the research design, introducing the research sample, data sources, variable setting and measurement model; the fourth part is the empirical results and analysis; the fifth part is the robustness test; the final part is conclusions and suggestions.

\section{Theoretical Analysis and Research Hypotheses}

Enterprise financing ability is the key factor of its growth and development. The 
research by Rajan and Zingles (1998) has shown that in financial-developed countries, industries with high financing dependency are also growing faster [14]. Enterprise Financing mode is generally divided into endogenous financing and exogenous financing, and enterprise endogenous financing mainly comes from the accumulation of savings within the enterprise, while exogenous financing is mainly from the outside of the enterprise, including debt financing and equity financing. Demirgüç-Kunt and Maksimovic (1998) use the financing plan model to prove that exogenous financing can improve the growth rate of enterprises. For fast-growing enterprises, internal financing often does not meet the investment needs of enterprises, so they are more inclined to external financing [15]. At present, the main financing mode of Chinese enterprises is debt financing, and equity financing has not yet become the main way for enterprises to accumulate capital and improve production efficiency, which is caused by the inefficiency of China's financial market (Shen Kunrong and Zhang Cheng, 2003) [16]. Under the financing constraint, the enterprise financing ability is limited, which will restrict all aspects of the enterprise development, including the business activities, investment behavior, $\mathrm{R} \& \mathrm{D}$ behavior, export behavior and enterprise performance (Minetti and Zhu, 2011; Li Ke and Xu Longbing, 2011; Li Zhiyuan and Yu Miaojie, 2013; Ju Xiaosheng and others, 2013; Liu Liya and others, 2015; Wu Xiaofen and others, 2018; Zhang Aimei and others, 2019) [1] [3] [4] [17] [18] [19] [20]. According to the above discussion, this paper puts forward the first hypothesis:

H1: Financing constraints which are negatively related to the growth of enterprises, will limit the growth of enterprises.

Because China's financial market level is not high, the development of the capital market is relatively lagging behind, the development of the legal system is not perfect, so enterprise financing mainly comes from the "system" financial institutions. Banks play a leading role in China's financial system, which means that banks, especially large state-owned banks, have a more important impact on corporate finance (Zhang Shikun, 2018; Fang Fang and Cai Weixing, 2016) [2] [21]. Under the asymmetry of information, financial institutions prefer to provide financial support to state-owned enterprises and large enterprises. However, private enterprises that need exogenous financing, especially small and medium-sized private enterprises, are more likely to fail to obtain financial support because of the lower expectations from financial institutions. The construction of social credit system can effectively alleviate the financing constraints faced by enterprises through the construction of credit information sharing mechanism and the construction of joint discredited punishment mechanism. The existing literature has proved that the credit environment and the construction of honesty culture have an important impact on enterprise financing. Guiso and others (2004) points that the establishment of the debt contract is based on a high degree of trust. In fact, the creditors take the opportunity cost of the current fund as a price to gain more benefits in the future. Although the principle of contract is to stipulate all the possibilities in the future fairly, it is difficult to 
achieve in reality under information asymmetry, so the success of the transaction depends not only on the binding force of law, but also on the degree of creditor's trust in the debtor [23]. Ma Hong (2010) also points out that social trust and network relationships can positively influence the financing capacity of the small and medium-sized enterprises, which help to reduce the degree of information asymmetry in the financing process, reduce the cost of enterprise financing and enhance the flexibility of financing contracts [22]. At the same time, it has been proved that the construction of credit system can improve the quality of bank loans, improve the availability of corporate loans and reduce the financing costs of enterprises (Qian Xianhang and Cao Chunfang, 2013; Li Daokui and others, 2016) [11] [24].

To sum up, the theoretical logic for the construction of social credit system to alleviate the impact of financing constraints on the growth of enterprises is that financing constraints restrict the growth of enterprises, and the construction of social credit system is conducive to alleviating financing constraints, making it easier for enterprises to obtain the credit support needed for the growth of enterprises. Accordingly, this paper proposes a second hypothesis:

$\mathrm{H} 2$ : The construction of social credit system can reduce information asymmetry on the one hand, and can govern the credit deficiency of market subjects on the other. The higher the level of Social Credit system construction, the better the credit environment, the more it can weaken the inhibitory effect of financing constraints on the growth of enterprises.

Many literatures have proved that the property rights nature of the enterprise will affect the financing constraints faced by enterprises. Because the financing environment and financing conditions of enterprises with different property rights nature are not the same, the impact of social credit system construction on the relationship between enterprise financing constraints and enterprise growth of different property rights nature will also vary. Based on the reality of our country, state-owned enterprises have inherent innate advantages, and it is easier for them to get the tilt of bank loan policy and loan preference, so as to obtain more financing support. In contrast, the loan conditions of private enterprises are more stringent, which is reflected in the loan approval conditions, approval process and loan amount, and all need to be strictly controlled by financial institutions. Therefore, small and medium-sized private enterprises that have already been financially constrained are facing significantly higher loan costs than large state-owned enterprises, which will create a vicious circle, further exacerbating the plight of private enterprises and small and medium-sized enterprises, leading them to reduce high-quality projects (Campello and others, 2011) [25]. What's more, corporate dishonesty occurs for they seek for short-term returns, which limits the growth of enterprises. Therefore, a transparent and fair financing environment for private enterprises is more urgent. The construction of social credit system can improve information sharing, broaden the external financing channels of enterprises and create a good financing environment for enterprises. Wei Zhihua and others (2014) indicate that the improvement of fi- 
nancial environment can help enterprises reduce the degree of financing constraints, but compared with state-owned enterprises, the improvement of financial environment makes private enterprise financing constraint coefficient decline more obviously [26]. Based on the above analysis, the third hypothesis of this paper is put forward:

H3: For different property nature Enterprises, there are differences in the impact of Social credit system construction level and financing constraints on the growth of enterprises.

\section{Research Design}

\subsection{Sample Selection and Data Description}

This paper takes the A-Share listed companies in Shanghai and Shenzhen from 2010 to 2017 as the initial sample, and the following steps are taken for the initial company data processing: 1) Select non-financial industry enterprises, because the financial industry data records have industry particularity; 2) Eliminate ST, ${ }^{*}$ ST listed companies and delisted companies; 3 ) Exclude observations where the relevant data is missing or abnormal; 4) Perform Winsorize tailing processing of $1 \%$ or less and $99 \%$ or more to remove the influence of outliers. Finally, this paper obtained 18,016 samples, a total of 2609 listed companies data. The enterprise-level research data of this paper and the macroeconomic data of each province are from the CSMAR database. The China City Commercial Credit Environment Index (CEI) used in this paper to reflect the level of social credit system construction is downloaded from the official website of this index.

\subsection{Model Design}

Based on the panel data of A-Share listed companies in Shanghai and Shenzhen in 2010-2017, this paper establishes a panel data model to test and analyze the above theories and hypotheses empirically. Firstly, the paper examines the relationship between financing constraints and enterprise growth, so the model (1) proves that the research hypothesis one. On the basis of the model (1), it adds the interaction of financing constraint and credit environment index, forming Model (2), which is used to test the research hypothesis two. Finally, according to the property right nature of the sample enterprises, test research hypothesis three. So, the model (1) and model (2) are set as follows:

$$
\begin{gathered}
\text { growth }_{i t}=\alpha_{0}+\alpha_{1} F C_{i t}+\alpha_{2} X_{i t}+\gamma_{i}+d_{j}+\mu_{t}+\varepsilon_{i t} \\
\text { growth }_{i t}=\beta_{0}+\beta_{1} C E I_{i t}+\beta_{2} F C_{i t}+\beta_{3} F C_{i t} * C E I_{i t}+\beta_{4} X_{i t}+\gamma_{i}+d_{j}+\mu_{t}+\varepsilon_{i t}
\end{gathered}
$$

In the above model, the interpreted variable growth $_{i t}$ represents the level of enterprise growth of enterprise $i$ in the year $\mathrm{t}$, mainly expressed by indicators reflecting the profitability and development ability of the enterprise. In the literature, some scholars will choose the growth rate of sales or the growth rate of enterprise workers as the agent variable to measure the growth of enterprises (Delmar and others, 2003; Chrisman and others, 2005) [27] [28], because the growth 
of enterprises is often accompanied by an increase in sales and enterprise size. In the existing literature, some scholars choose the operating income growth rate that reflects the profitability and development ability of enterprises to make the growth agent variable of enterprises (Fang Fang and Cai Weixing, 2016) [21]. According to previous practice, this paper selects the widely used operating income growth rate to measure the growth level of the company.

Explanatory variable $F C_{i t}$ represents the financing constraints faced by enterprise $i$ in year $t$. Because the financing constraint is a relatively abstract concept, there are many different representations in the previous research. There are many indicators of financing constraints. The commonly used models to measure financing constraints are investment cash flow measurement model (Fazzri, Hubbard \& Petersen, 1988) [29], KZ index model (Kaplan and Zingales, 1997) [30] and WW index (Li, 2011) [31]. Considering the endogenous problem, this paper selects the SA Index to measure the financing constraints faced by enterprises. The SA index is developed by Hadlock and Pierce on the KZ index, and it is also a widely used index. This paper draws on the practices of Xiao Xiaosheng (2013) [3] and Liu Liya (2015) [21], and directly uses the following formula to calculate the SA index of the enterprise. Its formula is as follows:

$$
\mathrm{SA}=-0.737 * \mathrm{Size}+0.043 * \mathrm{Size}^{2}-0.04 * \text { Age }
$$

SA index calculates a negative value, but the larger its value, the greater the corporate financing constraints. Size contained in the above formula refers to the total assets of the enterprise. According to the method of Liu Liya and others (2015) [20], processing data of total asset with a unit of one yuan into data with a unit of one million yuan is then brought in natural logarithm calculation. And Age uses the establishment years of the company. According to Hadlock and Pierce (2010) [32] and Liu Liya and others (2015) [20], this paper conducts tail processing of Size and Age at the $99 \%$ quantile when calculating SA index.

The explanatory variable $C E I_{i t}$ represents the level of social system construction in the province where enterprise $i$ was located in year $t$. It is measured by the China City Commercial Credit Environment Index (CEI), which is developed by China Market Society Credit Work Committee and China Institute of Management Science Integrity Evaluation Research Center and other units with a large number of domestic credit management experts, and it is mainly used to evaluate the state of domestic credit environment. The index has 6 first-level indicators, that is, the index from credit delivery, credit system, government credit supervision, breach of trust violations, corporate credit management and integrity education. The index score is limited to $60-100$, the higher the score the better credit environment of the city, the higher the level of social credit system construction (Lin Junyue, 2012) [33]. However, due to the lack of data, only the use of 29 provincial administrative regions of CEI score except for Hong Kong, Macao and Taiwan, as well as the Xinjiang Uygur Autonomous Region and Tibet Autonomous Region.

Control variables $X_{i t}$ control enterprise characteristics and urban characte- 
ristics. According to the established literature, the growth of enterprises may be influenced by the size, financial leverage, profitability and the establishment years of the company. Therefore, the control variables at the enterprise level in this paper include Enterprise Size (Size), Enterprise establishment years (Age), Enterprise Nature (Equitynature), Enterprise Profitability (ROS) and enterprise Debt level (Lev). Considering that the growth of enterprises may be affected by local macroeconomics, this paper further controls the gross product value of the province, expressed in logarithmic GDP. In addition, this paper also controls industry, annual and individual effects. The main variables and definitions are shown in Table 1.

\section{Analysis of Empirical Results}

\subsection{Description Statistics and Relevance Analysis}

Table 2 shows the descriptive statistical results of main variables. From the results of the table, it can be seen that the average annual operating income growth

Table 1. Main variable definition and description.

\begin{tabular}{cl}
\hline Variables & Definition \\
growth & operating income growth rate \\
FC & SA index \\
CEI & CEI provincial level index \\
Size & logarithm of total assets \\
Age & logarithm of establishment years \\
ROS & operating profit/main business income \\
Lev & liabilities/total assets \\
Equitynature & dumb variables classified into state-owned, private, foreign capital and others \\
GDP & logarithm of annual GDP
\end{tabular}

Data sources: CSMAR database.

Table 2. Descriptive statistics of major variables.

\begin{tabular}{cccccc}
\hline Variable & Sample & Mean & Standard Deviation & Min & Max \\
\hline growth & 18,016 & 0.231 & 0.583 & -0.562 & 4.330 \\
SA & 18,016 & -3.706 & 0.242 & -4.318 & -2.757 \\
CEI & 18,016 & 73.04 & 6.343 & 64.53 & 90.63 \\
Age & 18,016 & 2.673 & 0.413 & 1.3863 & 3.367 \\
Lev & 18,016 & 0.436 & 0.215 & 0.0483 & 0.940 \\
ROS & 18,016 & 0.0831 & 0.163 & -0.724 & 0.585 \\
Size & 18,016 & 8.252 & 1.287 & 5.641 & 12.18 \\
GDP & 18,016 & 10.31 & 0.703 & 7.208 & 11.40 \\
\hline
\end{tabular}

Data sources: CSMAR database. 
rate of enterprises during the sample period is about $23.1 \%$, which indicates that enterprises are in the stage of growing up rapidly, but the individual differences between enterprises are large. At the same time, it can be seen from the table that the mean value of CEI index is 73.04, indicating that the credit environment of Chinese enterprises is relatively good, but the standard deviation is 6.343 , which also reflects the development of social credit construction among regions in China is quite different, and the regional social credit system construction is unbalanced.

Table 3 shows the correlation coefficient table of the main variables in this paper. As can be seen from the table, the SA index is negatively correlated with the growth of the enterprise, which is consistent with the hypothesis of this paper, and it provides preliminary empirical evidence for the research hypothesis. However, since the correlation test does not take into account other factors, further rigorous empirical verification is required. Since the correlation coefficients between the main variables are below 0.5 , and the mean value of the variance inflation factor among the main variables is 2.66 , the concern about the effect of multiple collinearity on the results can be dispensed with.

\subsection{Basic Regression Results}

Before the empirical analysis, this paper first uses the fixed effect model to test whether the data has individual and time fixed effect, by constructing the two-way fixed effect model of enterprise growth and financing constraints, and the $\mathrm{F}$ value test is 1.39 , and the probability is 0.000 , which means that the result rejects the original hypothesis, so this paper selects the fixed effect model between instead of mixed regression model. Secondly, the Hausman test is further adopted. The original hypothesis of Hausman test is that there is no difference between fixed effect and random effect, and the result of Hausman test is 1217.18 , and the probability of the test is 0.000 , so the original hypothesis is rejected, and this paper chooses the two-way fixed effect model to study the relationship between enterprise growth and enterprise financing constraints.

Table 3. Correlation coefficient matrix of main variables.

\begin{tabular}{ccccccccc}
\hline & growth & SA & CEI & Age & Size & Lev & ROS & GDP \\
\hline growth & 1 & & & & & & & \\
SA & $-0.013^{*}$ & 1 & & & & & & \\
CEI & $-0.016^{* *}$ & $0.082^{* * *}$ & 1 & & & & & \\
Age & -0.001 & $-0.887^{* * *}$ & $-0.044^{* * *}$ & 1 & & & & \\
Size & $0.036^{* * *}$ & $-0.094^{* * *}$ & $0.084^{* * *}$ & $0.156^{* * *}$ & 1 & & \\
Lev & $0.045^{* * *}$ & $-0.172^{* * *}$ & $-0.042^{* * *}$ & $0.232^{* * *}$ & $0.465^{* * *}$ & 1 & & \\
ROS & $0.133^{* * *}$ & $0.014^{*}$ & $0.057^{* * *}$ & $-0.060^{* * *}$ & $0.091^{* * *}$ & $-0.334^{* * *}$ & 1 & \\
GDP & $-0.017^{* *}$ & $-0.023^{* * *}$ & $-0.178^{* * *}$ & $-0.018^{* *}$ & $-0.026^{* * *}$ & $-0.115^{* * *}$ & $0.060^{* * *}$ & 1 \\
\hline
\end{tabular}

$* * *, * *$, and ${ }^{*}$ represent the significance levels of $1 \%, 5 \%$ and $10 \%$, respectively. 
The first column of Table 4 shows the regression results of the pooled OLS model, and the second column is the regression results of the individual fixed effect model, controlling all the control variables, the industry effect, the nature of the enterprise and the individual effect. And the third column controls the time effect on the basis of the second column. In order to avoid the influence of self-correlation on enterprise standard error, all regression standard errors in the table are the clustering standard errors at the enterprise level. From the table we can see that the regression coefficient between financing constraints and enterprise growth is significantly negative, which shows that the looser the financing constraints received by enterprises, the better the growth of enterprises. This also validates the first research hypothesis in this paper that corporate financing constraints will limit the growth of enterprises. According to the test before the model selection, it may be more reasonable to explain the relationship using the two-way fixed effect model. Therefore, this paper mainly explains the relationship between the two based on two-way fixed effect model to. Judging from the regression results of control variables, the estimation coefficients of enterprise leverage (Lev), Enterprise Size (Size) and enterprise Profitability (ROS) are

Table 4. The impact of financing constraints on enterprise growth.

\begin{tabular}{|c|c|c|c|}
\hline & (1) & (2) & (3) \\
\hline & OLS & $\mathrm{FE}$ & $\mathrm{FE}$ \\
\hline \multirow[t]{2}{*}{ SA } & $-0.121^{\star *}$ & $-0.619^{* * *}$ & $-0.756^{* * *}$ \\
\hline & $(0.048)$ & $(0.166)$ & $(0.181)$ \\
\hline \multirow[t]{2}{*}{ Lev } & $0.331^{\star * \star}$ & $0.449^{\star * \star}$ & $0.427^{\star * *}$ \\
\hline & $(0.034)$ & $(0.071)$ & $(0.071)$ \\
\hline \multirow[t]{2}{*}{ ROS } & $0.628^{\star * *}$ & $0.835^{* * *}$ & $0.832^{* * *}$ \\
\hline & $(0.041)$ & $(0.068)$ & $(0.070)$ \\
\hline \multirow[t]{2}{*}{ Size } & $-0.015^{* * *}$ & $0.258^{\star * *}$ & $0.270^{\star * *}$ \\
\hline & $(0.005)$ & $(0.024)$ & $(0.025)$ \\
\hline \multirow[t]{2}{*}{ Age } & $-0.083^{* * *}$ & $-0.194^{\star * *}$ & $-0.171^{\star *}$ \\
\hline & $(0.027)$ & $(0.068)$ & $(0.071)$ \\
\hline \multirow[t]{2}{*}{ GDP } & $-0.014^{*}$ & $-0.596^{* * *}$ & $-0.244^{\star *}$ \\
\hline & $(0.008)$ & $(0.072)$ & $(0.117)$ \\
\hline \multirow[t]{2}{*}{ _cons } & 0.072 & $2.207^{\star * *}$ & -1.916 \\
\hline & $(0.147)$ & $(0.458)$ & $(1.307)$ \\
\hline Equitynature & $\mathrm{N}$ & $\mathrm{Y}$ & $\mathrm{Y}$ \\
\hline Industry & $\mathrm{N}$ & $\mathrm{Y}$ & $\mathrm{Y}$ \\
\hline Year & $\mathrm{N}$ & $\mathrm{N}$ & $\mathrm{Y}$ \\
\hline Individual & $\mathrm{N}$ & Y & $\mathrm{Y}$ \\
\hline $\mathrm{N}$ & 18,016 & 18,016 & 18,016 \\
\hline R-squared & 0.029 & 0.094 & 0.117 \\
\hline
\end{tabular}

Standard errors cluster at enterprise level are in parenthesis; ${ }^{* * *},{ }^{* *}$, and ${ }^{\star}$ represent the significance levels of $1 \%, 5 \%$ and $10 \%$, respectively. 
significantly positive, indicating that the larger the scale, the higher the leverage and the stronger the profitability, the higher the growth of enterprises.

The coefficient of establishment years of enterprises is significantly negative, indicating that the growth of new enterprises is better than that of old ones. It is somewhat unexpected that the scale of economic development and the growth of enterprises in their provinces are significantly negative. In fact, this also reflects that the better the macroeconomic development of the province where the enterprise is located, the higher the concentration of the enterprise, the fiercer the competition of the enterprise, which puts forward higher requirements for the growth and development of the enterprise. So, such an outcome is reasonable.

Table 5 analyzes the impact of the construction of social credit system on the

Table 5. The value of social credit system construction: financing constraints and corporate growth.

\begin{tabular}{|c|c|c|c|c|}
\hline & (1) & (2) & (3) & (4) \\
\hline & OLS & $\mathrm{FE}$ & $\mathrm{FE}$ & Center \& FE \\
\hline \multirow[t]{2}{*}{ SA } & $-0.417^{\star}$ & $-1.637^{\star * *}$ & $-1.755^{\star * *}$ & $-0.744^{\star \star \star}$ \\
\hline & $(0.214)$ & $(0.533)$ & $(0.546)$ & $(0.180)$ \\
\hline \multirow[t]{2}{*}{$\mathrm{CEI} * \mathrm{SA}$} & 0.004 & $0.014^{\star *}$ & $0.014^{* *}$ & $0.014^{* *}$ \\
\hline & $(0.003)$ & $(0.007)$ & $(0.007)$ & $(0.007)$ \\
\hline \multirow[t]{2}{*}{ CEI } & 0.013 & 0.042 & 0.042 & $-0.010^{* * *}$ \\
\hline & $(0.010)$ & $(0.026)$ & $(0.027)$ & $(0.003)$ \\
\hline \multirow[t]{2}{*}{ Lev } & $0.326^{* * *}$ & $0.449^{* * *}$ & $0.437^{* * *}$ & $0.437^{* * *}$ \\
\hline & $(0.035)$ & $(0.071)$ & $(0.071)$ & $(0.071)$ \\
\hline \multirow[t]{2}{*}{ ROS } & $0.631^{\star * *}$ & $0.808^{* * *}$ & $0.834^{* * *}$ & $0.834^{* * *}$ \\
\hline & $(0.041)$ & $(0.069)$ & $(0.070)$ & $(0.070)$ \\
\hline \multirow[t]{2}{*}{ Size } & $-0.015^{\star * *}$ & $0.252^{\star \star \star}$ & $0.272^{\star \star \star}$ & $0.272^{\star * *}$ \\
\hline & $(0.005)$ & $(0.024)$ & $(0.024)$ & $(0.024)$ \\
\hline \multirow[t]{2}{*}{ Age } & $-0.084^{* * *}$ & $-0.155^{\star *}$ & $-0.164^{* *}$ & $-0.164^{* *}$ \\
\hline & $(0.028)$ & $(0.069)$ & $(0.070)$ & $(0.070)$ \\
\hline \multirow[t]{2}{*}{ GDP } & $-0.017^{\star *}$ & $-0.203^{\star}$ & -0.184 & -0.184 \\
\hline & $(0.008)$ & $(0.117)$ & $(0.119)$ & $(0.119)$ \\
\hline \multirow[t]{2}{*}{ _cons } & -0.854 & $-4.830^{* *}$ & $-5.567^{\star *}$ & -1.819 \\
\hline & $(0.756)$ & $(2.276)$ & (2.335) & (1.315) \\
\hline Equitynature & $\mathrm{N}$ & $\mathrm{N}$ & $\mathrm{Y}$ & $\mathrm{Y}$ \\
\hline Industry & $\mathrm{N}$ & $\mathrm{N}$ & $\mathrm{Y}$ & $\mathrm{Y}$ \\
\hline Year & $\mathrm{N}$ & Y & $\mathrm{Y}$ & $\mathrm{Y}$ \\
\hline Individual & $\mathrm{N}$ & $\mathrm{Y}$ & $\mathrm{Y}$ & $\mathrm{Y}$ \\
\hline $\mathrm{N}$ & 18,016 & 18,016 & 18,016 & 18,016 \\
\hline R-squared & 0.029 & 0.102 & 0.119 & 0.119 \\
\hline
\end{tabular}

Standard errors cluster at enterprise level are in parenthesis; ${ }^{* *},{ }^{* *}$, and ${ }^{*}$ represent the significance levels of $1 \%, 5 \%$ and $10 \%$, respectively. 
relationship between enterprise financing constraints and enterprise growth. Column (1) reflects the empirical results of the pooled OLS model, and according to the fixed effect $\mathrm{F}$ test and Hausman test, the fixed effect model is chosen to verify the impact of the construction of social credit system on the relationship between financing constraints and growth of enterprises. Column (2) and column (3) are applied to two-way fixed model. Column (2) does not control the nature and industry effects of the enterprise, while the column (3) adds all the control variables and fixed effects mentioned above to the model. It can be seen that financing constraints and firm growth are negatively correlated, which proves the research hypothesis once again. The interaction coefficient of social credit system construction and financing constraint is positive, which shows that the construction of social credit system can alleviate the influence of financing constraint on enterprise growth. In order to prevent the collinearity problem from influencing the conclusions of this paper, the centralization of the main explanatory variables and the regression test are carried out. The results are shown in column (4). Specifically, when the CEI index reflecting the mean value 73.04 , the financing constraints increase by 1 , the growth of enterprises will be reduced by 0.732 . If the construction of social credit system can not inhibit the effect of financing constraints, the negative impact on the growth of enterprises is much greater than 0.74 when the financing constraints increase by 1 . This shows that the construction of social credit system can alleviate the impact of financing constraints on the growth of enterprises, the second research hypothesis has been verified. The coefficient of CEI in the fourth column is negative, which shows that when the financing constraint of an enterprise reaches the mean, the construction of social credit system will restrict the growth of enterprises. This may be because the key mechanism of the current social credit system construction is the joint discredited punishment mechanism, which is a direct and severe blow to the corporate breach of trust, so that the discredited enterprises face "Lost trust, limited everywhere" situation. It makes enterprises tend to pursue long-term interests rather than short-term returns when making business decisions. Therefore, enterprises with high levels of social credit system construction may change their business decisions because of the increase cost of losing trust, which will affect their short-term growth.

In order to further study the heterogeneity on the influence of construction of social credit system and the financing constraints on the growth of enterprises in different ownership enterprises, this paper divides the whole sample into two groups of state-owned and non-state-owned samples according to the nature of the enterprise. Table 6 column (1) and (2) show the regression results after the main variables are centered. It shows that the construction of social credit system has little effect on the mitigation of financing constraints of state-owned enterprises, not statistically significant. Although the financing constraint has a negative relationship with the growth of state-owned enterprises, it is not statistically significant. In contrast, the financing constraints significantly limit the 
Table 6. The value comparison of social credit system construction between state-owned enterprises and non-state-owned enterprises.

\begin{tabular}{|c|c|c|}
\hline & $\begin{array}{c}(1) \\
\text { State-owned }\end{array}$ & $\begin{array}{c}(2) \\
\text { Non-state-owned }\end{array}$ \\
\hline \multirow[t]{2}{*}{ SA } & -0.277 & $-1.382^{\star * *}$ \\
\hline & $(0.238)$ & $(0.271)$ \\
\hline \multirow[t]{2}{*}{$\mathrm{CEI}{ }^{*} \mathrm{SA}$} & -0.003 & $0.023^{* *}$ \\
\hline & $(0.009)$ & $(0.010)$ \\
\hline \multirow[t]{2}{*}{ CEI } & $-0.008^{*}$ & $-0.015^{\star * *}$ \\
\hline & $(0.004)$ & $(0.005)$ \\
\hline \multirow[t]{2}{*}{ Lev } & $0.383^{* * *}$ & $0.462^{* * *}$ \\
\hline & $(0.112)$ & $(0.096)$ \\
\hline \multirow[t]{2}{*}{ ROS } & $0.721^{\star * *}$ & $0.928^{* * *}$ \\
\hline & $(0.102)$ & $(0.089)$ \\
\hline \multirow[t]{2}{*}{ Size } & $0.364^{* * *}$ & $0.233^{* * *}$ \\
\hline & $(0.038)$ & $(0.035)$ \\
\hline \multirow[t]{2}{*}{ Age } & -0.069 & -0.105 \\
\hline & $(0.129)$ & $(0.090)$ \\
\hline \multirow[t]{2}{*}{ GDP } & -0.148 & -0.110 \\
\hline & $(0.128)$ & $(0.185)$ \\
\hline \multirow[t]{2}{*}{ _cons } & -2.089 & -3.048 \\
\hline & (1.530) & (1.979) \\
\hline Equitynature & Y & $\mathrm{Y}$ \\
\hline Industry & Y & Y \\
\hline Year & Y & $\mathrm{Y}$ \\
\hline Individual & Y & $\mathrm{Y}$ \\
\hline $\mathrm{N}$ & 7221 & 10,795 \\
\hline R-squared & 0.129 & 0.134 \\
\hline
\end{tabular}

Standard errors cluster at enterprise level are in parenthesis; ${ }^{* *},{ }^{* *}$, and ${ }^{*}$ represent the significance levels of $1 \%, 5 \%$ and $10 \%$, respectively.

growth and development of the non-state-owned enterprises, but the construction of social credit system on the mitigation of financing constraints is significant. When the level of social credit system construction is 73.04 , for every 1 increase in financing constraints, the growth of non-state-owned enterprises will be reduced by 1.382. Compared with results of these two groups of samples, the impact of financing constraints on the growth of non-state-owned enterprises is more obvious. Because state-owned enterprises are within the system and have natural political connection, they have easier access to financing resources. But non-state-owned enterprises and financial institutions are under the circumstance of information asymmetry, it will lead to "credit discrimination" situation 
when both sides can not accurately grasp each other's information situation. Therefore, the financing constraints of state-owned enterprises have little impact on the growth of enterprises, but they have an important impact on non-state-owned enterprises. and the mitigation effect of social credit system construction on financing constraints is also more effective for non-state-owned enterprises. So, the research hypothesis 3 of this paper has also been verified.

\section{Robustness Check}

Although the concept of credit system construction in China has been implemented gradually since the 1999, it has been paid more and more attention, and the whole country has been implemented since 2014, and the Outline of Social Credit System Construction Planning (2014-2020) can be regarded as a sign of the formal and comprehensive start of the construction of social credit system. Under such exogenous shocks, the impact of social credit system construction will also change. Taking 2014 as a time point, this paper examines the impact of social credit system on the mitigation of corporate financing constraints before and after the event. The results are shown in Table 7. In this part, the samples are divided into two groups according to the time period, and the regression is after centralization of major variables. Through the results, it is found that the negative effect of financing constraints on the growth of enterprises is significant in both groups of samples, and the construction of social credit system can play a role in slowing down financing constraints. After the promulgation of the outline, it strengthens the role of social credit system in relieving the impact of financing constraints on the growth of enterprises. This conclusion is consistent with the above conclusion, which further verifies the mitigation effect of social credit system on enterprise financing constraints.

\section{Conclusions and Suggestions}

This paper analyzes the role of social credit system construction in financing constraints and enterprise growth, especially the role of social credit system construction in mitigating the impact of financing constraints on the growth of enterprises. In the test of enterprises from 2010 to 2017, this paper finds that financing constraints will restrict the growth of enterprises, and the construction of social credit system can effectively alleviate the impact of financing constraints on the growth of enterprises. On this basis, this paper further studies the impact of construction of social credit system and financing constraints on different ownership enterprises growth, finding that compared with the state-owned enterprises, non-state-owned enterprises are more vulnerable to financing constraints, and financing constraints are more significant for the growth of enterprises. At the same time, the mitigation effect of social credit system construction on financing constraints is more important and valuable for non-state-owned enterprises.

Social credit system is an important institution that can alleviate the restriction of financing constraints on the growth of enterprises, and it is an infrastructure 
Table 7. Promulgation of the outline, construction of social credit system and restriction of enterprise financing.

\begin{tabular}{|c|c|c|}
\hline & $\begin{array}{c}(1) \\
2010-2013\end{array}$ & $\begin{array}{c}(2) \\
2014-2017\end{array}$ \\
\hline \multirow[t]{2}{*}{ SA } & $-2.014^{* * *}$ & $-0.908^{* * *}$ \\
\hline & $(0.277)$ & $(0.198)$ \\
\hline \multirow[t]{2}{*}{$\mathrm{CEI} * \mathrm{SA}$} & 0.011 & $0.054^{* * *}$ \\
\hline & $(0.012)$ & $(0.015)$ \\
\hline \multirow[t]{2}{*}{ CEI } & -0.008 & $-0.013^{\star}$ \\
\hline & $(0.007)$ & $(0.007)$ \\
\hline \multirow[t]{2}{*}{ ROS } & $1.061^{\star * *}$ & $0.854^{\star \star *}$ \\
\hline & $(0.074)$ & $(0.056)$ \\
\hline \multirow[t]{2}{*}{ Lev } & $0.703^{\star * *}$ & $0.237^{\star * *}$ \\
\hline & $(0.103)$ & $(0.080)$ \\
\hline \multirow[t]{2}{*}{ Size } & $0.315^{\star * *}$ & $0.486^{* * *}$ \\
\hline & $(0.034)$ & $(0.022)$ \\
\hline \multirow[t]{2}{*}{ Age } & $-0.404^{\star *}$ & $-0.530^{* * *}$ \\
\hline & $(0.184)$ & $(0.185)$ \\
\hline \multirow[t]{2}{*}{ GDP } & -0.293 & $-0.307^{\star *}$ \\
\hline & $(0.256)$ & $(0.144)$ \\
\hline \multirow[t]{2}{*}{ _cons } & 1.449 & 0.749 \\
\hline & $(2.621)$ & $(1.613)$ \\
\hline Equitynature & Y & Y \\
\hline Industry & $\mathrm{Y}$ & $\mathrm{Y}$ \\
\hline Year & $\mathrm{Y}$ & $\mathrm{Y}$ \\
\hline Individual & $\mathrm{Y}$ & $\mathrm{Y}$ \\
\hline $\mathrm{N}$ & 7806 & 10,210 \\
\hline R-squared & 0.153 & 0.183 \\
\hline
\end{tabular}

Standard errors cluster at enterprise level are in parenthesis; ${ }^{* *},{ }^{* *}$, and ${ }^{*}$ represent the significance levels of $1 \%, 5 \%$ and $10 \%$, respectively.

that needs long-term development and firm implementation. The two mechanisms of social credit system construction, credit information sharing mechanism and joint discredited punishment mechanism, can effectively slow down the impact of financing constraints on enterprise growth. At present, the construction of China's social credit system is still in its infancy, the development of the two mechanisms is still imperfect, and a good social credit system environment has not yet been established yet. In order to give full play to the promotion of the construction of social credit system to the growth of enterprises, this paper holds that we should start from the following aspects: Firstly, to reduce the problem of moral hazard and adverse selection caused by the asymmetry of credit informa- 
tion, we need to perfect the credit law, break the information monopoly of the department or industry, and strengthen the construction of enterprise credit information database. There is a need to expand the scope of information collection in order to provide more comprehensive information for financial institutions. In the information collection, in addition to the black information of the enterprise, the white information of the enterprise should also be collected. However, at present, the main information of white information of Chinese enterprises comes from the voluntary disclosure of enterprises and the quality and credibility of the information cannot be guaranteed. Therefore, the collection and confirmation of white information is an important direction for the future development of credit information sharing. Secondly, to govern the dishonesty of enterprises and increase the cost of dishonesty, we need to realize the function of joint punishment. For example, the "blacklist" system in our country needs the support of relevant laws and regulations to make the punishment of dishonesty legitimate and reasonable. While alleviating the financial and institutional pressures faced by enterprises, the implementation of a combination of punishment and incentives requires both pre-prevention mechanism and ex post punishment mechanism for corporate dishonesty. Finally, it is necessary to cultivate enterprise credit culture, promote enterprise credit management, improve the credit environment for non-state-owned enterprises, especially small and medium-sized enterprises, make integrity produce moral constraints, and then improve enterprise credit awareness, and create a good social credit atmosphere.

\section{Conflicts of Interest}

The author declares no conflicts of interest regarding the publication of this paper.

\section{References}

[1] Zhang, A.M., Guo, J.S. and Wu, W.H. (2019) Financing Constraints, Foreign Direct Investment and Enterprise Performance. Industrial Technology Economy, 38, 151-160.

[2] Zhang, S.K. (2018) Financing Constraints, Financial Marketization and Enterprise Export Behavior. Management World, 34, 175-176.

[3] Ju, X.S., Lu, D. and Yu, Y.H. (2013) Financing Constraints, Working Capital Management and Enterprise Innovation Sustainability. Economic Research, 48, 4-16.

[4] Wu, X.F., Liang, A.Q., Li, F. and Jiang, X. (2018) Institutional Credit Environment, Financing Constraints and Enterprise Innovation. Inquiry into Economic Issues, No. $12,70-80$.

[5] Marris, R. (1963) A Model of the "Managerial” Enterprise. The Quarterly Journal of Economics, 77, 185-209. https://doi.org/10.2307/1884399

[6] Eisenhardt, K.M. and Schoonhoven, C.B. (1990) Organizational Growth: Linking Founding Team, Strategy, Environment, and Growth Among U.S. Semiconductor Ventures, 1978-1988. Administrative Science Quarterly, 35, 504-529. https://doi.org/10.2307/2393315

[7] Rao, P.G. and Jiang, G.H. (2013) Monetary Policy, Credit Resource Allocation and 
Enterprise Performance. Management World, No. 3, 12-22.

[8] Zhang, X.M. and Zhang, T.T. (2016) Credit Discrimination, Commercial Credit and Capital Allocation Efficiency. Research on Economics and Management, 37, 26-33.

[9] Zhang, J. (2000) Financial Dilemma and Financing Order of Private Economy. Economic Research, No. 4, 3-10.

[10] Zhao, C., Zhou, Q. and Wang, J. (2012) Credit Propensity, Financing Constraint and SEMs Growth-Based on the Data in the Yangtze River Delta. China Industrial Economics, No. 9, 77-88.

[11] Qian, X.H. and Cao, C.F. (2013) Does Credit Environment Affect Bank Loan Portfolio: An Empirical Study Based on City Commercial Banks. Journal of Financial Research, No. 4, 57-70.

[12] Qian X.H. and Cao, T.Q. (2015) Law, Credit and Bank Loan Decision-making: Evidence from Shandong Province. Journal of Financial Research, No. 5, 101-116.

[13] Chen, Y. (2016) Empirical Study on the Relationship between Corporate Social Responsibility and Financial Performance. Thesis, Nanjing University of Finance and Economics, Nanjing.

[14] Rajan, R.G. and Zingales, L. (1998) Financial Dependence and Growth. The American Economic Review, 88, 559-586.

[15] Demirgüç-Kunt, A. and Maksimovic, V. (1998) Law, Finance, and Firm Growth. The Journal of Finance, 53, 2107-2137. https://doi.org/10.1111/0022-1082.00084

[16] Shen, K.R. and Zhang, C. (2003) Foreign Financing and Enterprise Growth of Chinese Enterprises: A Case Study of Listed Companies. Management World, No. 7, 120-126.

[17] Minetti, R. and Zhu, S. (2011) Credit constraints and firm export: Microeconomic evidence from Italy. Journal of International Economics, 83, 109-125. https://doi.org/10.1016/j.jinteco.2010.12.004

[18] Li, K. and Xu, L.B. (2011) Financing Constraints, Debt Capacity and Corporate Performance. Economic Research, 46, 61-73.

[19] Li, Z.Y. and Yu, M.S. (2013) Productivity, Credit Constraints and Enterprise Export: An Analysis Based on Chinese Enterprises. Economic Research, 48, 85-99.

[20] Liu, L.Y., He, Y.L., Wang, Z.F. and Cheng T.X. (2015) Will Financing Constraints Affect Foreign Direct Investment of Chinese Enterprises: A Theoretical and Empirical Analysis Based on Microeconomic Perspective. Journal of Financial Research, No. 8, 124-140.

[21] Fang, F. and Cai, W.X. (2016) Banking Competition and Enterprise Growth: Empirical Evidence from Industrial Enterprises. Management World, No. 7, 63-75.

[22] Ma, H. (2010) Social Capital and Financing Constraints of Small and Medium-sized Enterprises. Economic Problem, No. 12, 68-72.

[23] Guiso, L., Sapienza, P. and Zingales, L. (2004) The Role of Social Capital in Financial Development. The American Economic Review, 94, 526-556. https://doi.org/10.1257/0002828041464498

[24] Li, D.K., Liu, C. and Pang J.R. (2016) Research on the Promotion of Financial Infrastructure to Economic Development: A Case Study of China's Credit Reporting System. Journal of Financial Research, No. 2, 180-188.

[25] Campello, M.H., Giambona, E., Graham, J.R. and Harvey, C.R. (2011) Liquidity Management and Corporate Investment during a Financial Crisis. The Review of Financial Studies, 24, 1944-1979. https://doi.org/10.1093/rfs/hhq131 
[26] Wei, Z.H., Zeng, A.M. and Li, B. (2014) Financial Eco-Environment and Corporate Financing Constraints: An Empirical Study Based on Chinese Listed Companies. Accounting Research, No. 5, 73-80.

[27] Delmar, F., Davidsson, P. and Gartner, W.B. (2003) Arriving at the High Growth Firm. Journal of Business Venturing, 18, 189-216. https://doi.org/10.1016/S0883-9026(02)00080-0

[28] Chrisman, J.J., McMullan, E. and Hall, J. (2005) The Influence of Guided Preparation on the Long-Term Performance of New Ventures. Journal of Business Venturing, 20, 769-791. https://doi.org/10.1016/j.jbusvent.2004.10.001

[29] Fazzari, S.M., Hubbard, R.G., Petersen, B.C., Blinder, A.S. and Poterba, J. M. (1988) Financing Constraints and Corporate Investment. Brookings Papers on Economic Activity, 1, 141-206. https://doi.org/10.2307/2534426

[30] Kaplan, S.N. and Zingales, L. (1995) Do Financing Constraints Explain Why Investment Is Correlated with Cash Flow? NBER Working Paper, No. 5267.

[31] Li, D.M. (2011) Financial Constraints, R \& D Investment, and Stock Returns. The Review of Financial Studies, 24, 2974-3007. https://doi.org/10.1093/rfs/hhr043

[32] Hadlock, C.J. and Pierce, J.R. (2010) New Evidence on Measuring Financial Constraints: Moving Beyond the KZ Index. The Review of Financial Studies, 23, 1909-1940. https://doi.org/10.1093/rfs/hhq009

[33] Lin, J.Y. (2012) Development and Analysis of China's City Commercial Credit Environment Index. Finance and Trade Economics, No. 2, 89-97. 